\title{
GROWTH FEATURES OF AN ENDEMIC POPULATION OF CHONDROSTOMA HOLMWOODII (ACTINOPTERYGII: CYPRINIFORMES: CYPRINIDAE) IN WESTERN ANATOLIA
}

\author{
Ali İLHAN*, Hasan M. SARI, and Süleyman BALIK \\ Ege University, Faculty of Fisheries, 35100 Bornova-İzmir, Turkey
}

İlhan A., Sarı H.M., Balık S. 2010. Growth features of an endemic population of Chondrostoma holmwoodii (Actinopterygii: Cypriniformes: Cyprinidae) in western Anatolia. Acta Ichthyol. Piscat. 42 (2): 155-159.

Background. The Izmir nase, Chondrostoma holmwoodii (Boulenger, 1896), an endemic species for the inland waters of Turkey, is in the category of DD "Data Deficient" in the list of IUCN Red Data Book. There are insufficient data on the biological characteristics of the species in the literature. The aim of this study was to obtain the growth characteristics of Izmir nase population from Western Anatolia and compare them with the previous data reported in literature.

Materials and Methods. Biological features of Izmir nase were examined based on a total of 1208 specimens collected from Tahtalı Dam Lake during the period May 2006-April 2007. Age of fish was determined by reading scales. Length-weight relation and the von Bertalanffy equation were used to evaluate the fish growth.

Results. Scales reading indicated the presence of 5 age classes. The computed growth parameters were: $L_{\infty}=29.19 \mathrm{~cm}, k=0.177 \cdot$ year $^{-1}$ and $t_{0}=-3.258$ year $^{-1}$ for both sexes. The length-weight relations were estimated as $W=0.019 L^{2.97}, W=0.012 L^{3.11}$ and $W=0.011 L^{3.13}$ for females, males, and both sexes combined, respectively. Conclusion. The Izmir nase from Tahtalı Dam Lake was characterized by linear growth and it was observed that the fish grew faster during the first two years. Many endemic fish species in inland waters of Turkey are under the threat of extinction due to human activities (pollution, drought, dam construction, habitat degradation, and overfishing) but the species is not threatened by these factors in the study area.

Keywords: growth, population structure, Chondrostoma holmwoodii, Izmir nase, Tahtalı Dam Lake

\section{INTRODUCTION}

The Tahtalı Dam, located in the city of İzmir and Menderes town, receives its waters from the Şaşal and Bulgurca streams (Fig. 1). The dam was constructed to provide water for domestic and industrial purposes for İzmir, and was commissioned in 1999. Its area and volume are $24 \mathrm{~km}^{2}$ and $0.307 \mathrm{~km}^{3}$, respectively (Anonymous 2007).

All the previous studies on Tahtal1 Reservoir were carried out before the construction of the dam on the Gümüldür Brook, on which the dam lake is located. This study reported, information about the fish, reptile, and amphibian faunas in the Gümüldür Brook and its tributaries. Studies on the fish from the Tahtalı Dam Basin were initiated when "Leucalburnus kosswigi" [=Squalius cephalus (Linnaeus, 1758)] was first introduced from the Gümüldür Brook (Karaman 1972). Balık (1979) and Sarsu (unpublished ${ }^{* *}$ ) reported the taxonomical and ecological features of freshwater fishes in West Anatolia freshwaters and the Gümüldür Brook, respectively. Balık et al. (1995) studied the vertebrate fauna of the same area.

The first record of Chondrostoma holmwoodii from the inland waters of Turkey was reported by Boulenger (1896) as Capoeta holmwoodii. Later, the species was stated as Varicorhinus holmwoodi by Pellegrin (1928), as Chondrostoma nasus by Kosswig and Battalgil (1943), as Chondrostoma nasus, Chondrostoma regium, and Chondrostoma knerii by Ladiges (1960, 1966), as Chondrostoma nasus holmwoodi by Karaman (1969), respectively. Elvira (1987) divided the species into two subspecies, which are Chondrostoma holmwoodii holmwoodii from the Bakırçay and Gediz River basins and Chondrostoma holmwoodii meandrensis from the Büyük Menderes River Basin. At present, the Bakırçay and Gediz rivers populations of the species is determined as Chondrostoma holmwoodii while the Büyük Menderes River population as Chondrostoma meandrense (see Froese and Pauly 2009).

The biology of the species was also investigated in the Gediz River by Mermer and Balık (1991) Chondrostoma holmwoodii, is endemic to the inland waters of Turkey, and is classified as DD "Data Deficient" in the list of IUCN Red Data Book (Crivelli 2006). Pollution and water extraction are the main factors that negatively affect the fish populations (Crivelli 2006).

\footnotetext{
* Correspondence: Dr. Ali İlhan, Ege Üniversitesi, Su Ürünleri Fakültesi, Su Ürünleri Temel Bilimler Bölümü, İç Sular Biyolojisi Anabilim Dal, 35100 Bornova-İzmir, Türkiye, phone: (+90 232) 3884000/455345, e-mail: alilhan73@gmail.com or ali.ilhan@ege.edu.tr

${ }^{* *}$ Sarsu M. 1981. Gümüldür deresi ve ona bağlı kaynaklarda yaşayan tatlısu balıklarının taksonomisi ve ekolojik özellikleri üzerine ön çalışmalar. [A preliminary study on the taxonomical and ecological features of freshwater fishes in Gümüldür Stream and its tributaries.] Ege Üniversitesi Fen Fakültesi Biyolojik Oseanografi Bölümü (Diploma Tezi). [In Turkish].
} 


\section{MATERIALS AND METHODS}

Specimens of Chondrostoma holmwoodi were caught monthly during May 2006-April 2007 by 20, 25, 30, and $32 \mathrm{~mm}$ mesh trammel nets. Sampling was done between sunset and dawn every month in the same area.

A total of 1208 Izmir nase specimens were examined during the study period. Fish samples were fixed in $4 \%$ formaldehyde solution in the field and were measured in $\mathrm{mm}$ (fork length, FL), weighed to the nearest $0.01 \mathrm{~g}$ (total weight, $W$ ), and dissected in the laboratory.

Age was determined by reading scales. Some 15-20 scales from the left side of the body between the lateral line and dorsal fin were removed (Tesch 1970). Scales were prepared by applying a series of alcohol dilutives, and read under a binocular microscope.To minimize reading errors, the number of opaque rings outside the nucleus was evaluated by two readers.

Sex and maturity stages were determined by visual and microscopic examination of gonads.

The commonly used Ricker (1975) length-weight relation model was applied:

$$
W=a L^{b}
$$

where $W$ is the total weight (mass) [g], $L$ is the fork length [cm], $a$ and $b$ are the regression constants. Growth type was identified using the test (2-sided) (Sparre et al. 1989).

The generalized von Bertalanffy growth equations were used to describe the growth of the species (Sparre et al. 1989).

and

$$
L_{t}=L_{\sharp}\left(1-e^{-k\left(t-t_{0}\right)}\right)
$$

$$
W_{t}=W_{\infty}\left[\left(1-e^{-k\left(t-t_{0}\right)}\right]^{\mathrm{b}}\right.
$$

where $L_{t}$ and $W_{t}$ are the fish length and weight at age $t ; L_{\infty}$ and $W_{\infty}$ represent the asymptotic length and weight; $k$ is a relative growth coefficient and $t_{0}$ theoretical age when fish length is zero.

Natural mortality was calculated by using the formula of Pauly (1980):

$\log M=-0.0066-0.279 \log L_{\infty}+0.6543 \log k+0.4634 \log T$ where $M$ is the natural mortality, $k$ is the relative growth coefficient, and $T$ is the average annual water temperature. $T$ is the mean value of the measured temperature values during the field study (12 months).

\section{RESULTS}

The sex composition for the 1208 specimens of Chondrostoma holmwoodii was $72.10 \%: 27.90 \%$ (871 females : 337 males). According to the Chi-square test $\left(c^{2}\right)$ there was a significant difference in the female : male ratio of sampled fishes $\left(c^{2}=236.06<c^{2}{ }_{t 0.05}=3.841\right.$, $P \leq 0.05)$, whereby females significantly outnumbered males by a female : male ratio of $1: 0.39$. The age of the fish ranged from 1 to 5 years. Determination of the fish age showed that $39.49 \%$ of all samples belonged to age group IV. Age group I was represented by only $2.24 \%$ (Table 1).

The 1208 specimens ranged in length from 13.60 to $24.70 \mathrm{~cm} \mathrm{FL}$. FL of the males ranged from 13.60 to 24.00 $\mathrm{cm}$ and females from 14.40 to $24.70 \mathrm{~cm}$. An F test showed that there were significant differences between the length frequency distributions of female and male fish $(F=164.652$, $P<0.05, \mathrm{df}=1208-1)$. For this reason, the population analysis was carried out separately for females and males and for the two sexes combined. According to the length frequency distribution, specimens of $>20 \mathrm{~cm}(69.45 \%)$ were abundant for both sexes (Fig. 2).

When we compared the mean fork length of specimens, overall mean FL values of females were significantly higher than that of males (Table 2).

The weight distribution of specimens varied between 44.30 and $260.80 \mathrm{~g}$ for females, and $38.00 \mathrm{~g}$ and $237.00 \mathrm{~g}$ for males. According to this data, the mean weight values were higher for females than for males in all age groups (Table 2).

The von Bertallanffy growth equations of the population were computed as $L_{\infty}=29.19 \mathrm{~cm}$ and $W_{\infty}=438.80 \mathrm{~g}$ (Table 3).

Length-weight regression parameters for females, males and all individuals are presented in Table 4.
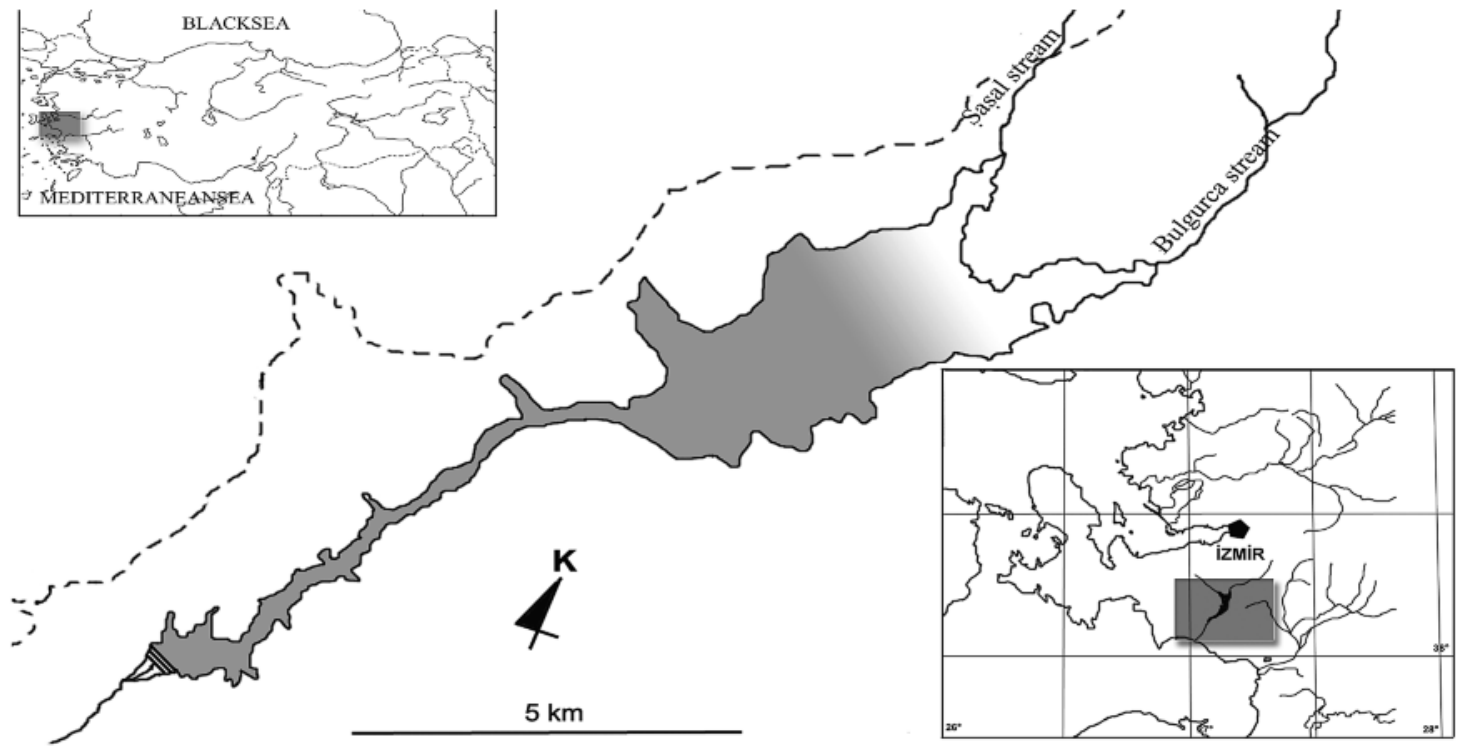

Fig. 1. Map of the study area (Tahtalı Dam Lake) 
Significant difference in the allometric coefficient was $(b=3.111 ; \pm \mathrm{SE}(b)=0.0706 ; P>0.05)$. Positive allometfound between females and males. According to Student's ric growth was observed for all specimens combined $t$-test, there were an isometric growth for females $(b=3.128 ; \pm \mathrm{SE}(b)=0.0355 ; P<0.05)$ (Table 4). $(b=2.971 ; \pm \mathrm{SE}(b)=0.0424 ; P>0.05)$, and males Correlation coefficients computed for the length-weight

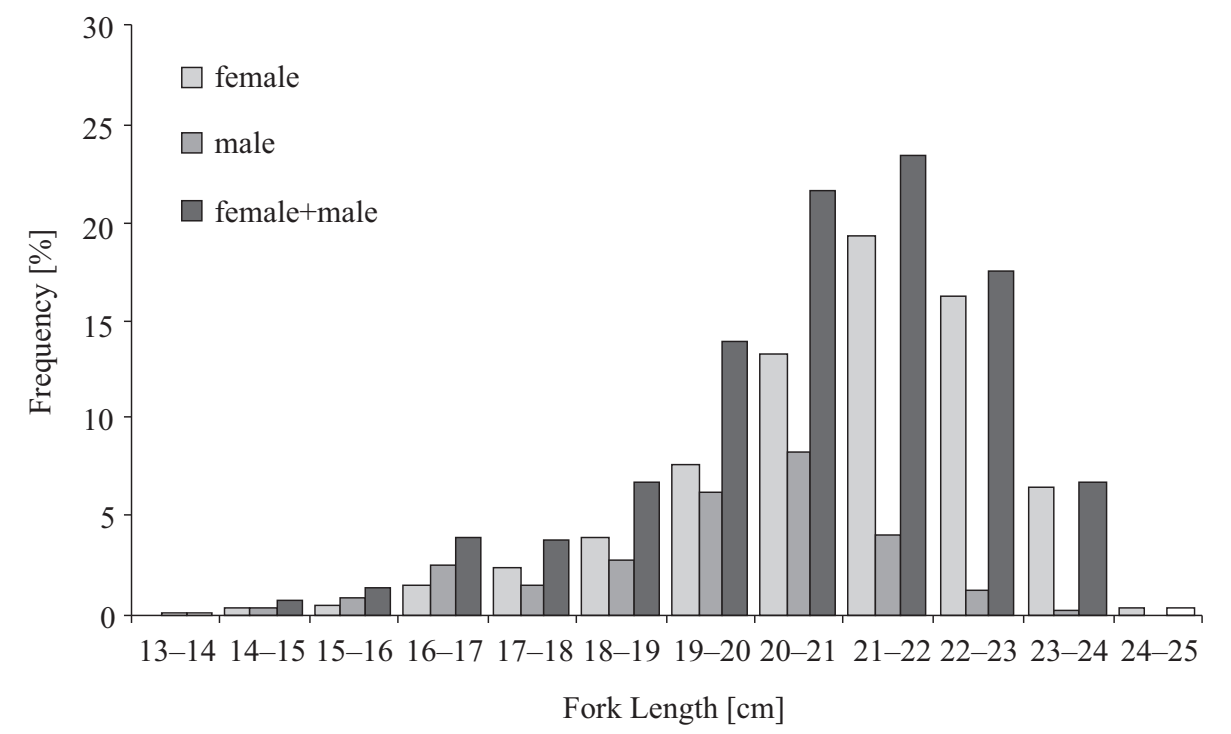

Fig. 2. Fork length frequency of Chondrostoma holmwoodii population of Tahtalı Dam Lake

The age and sex ratio of Chondrostoma holmwoodii population of Tahtalı Dam Lake

Table 1

\begin{tabular}{lrrrrrrl}
\hline \multirow{2}{*}{$\begin{array}{l}\text { Age } \\
\text { group }\end{array}$} & \multicolumn{2}{c}{ Female } & \multicolumn{2}{c}{ Male } & \multicolumn{2}{c}{ Female + Male } & \multirow{2}{*}{ Female : Male } \\
\cline { 2 - 6 } & \multicolumn{1}{c}{$n$} & \multicolumn{1}{c}{$\%$} & \multicolumn{1}{c}{$n$} & \multicolumn{1}{c}{$\%$} & \multicolumn{1}{c}{$n$} & \multicolumn{1}{l}{ M } & \\
\hline I & 14 & 1.16 & 13 & 1.08 & 27 & 2.24 & $1: 0.93$ \\
II & 69 & 5.71 & 62 & 5.13 & 131 & 10.84 & $1: 0.90$ \\
III & 124 & 10.26 & 100 & 8.28 & 224 & 18.54 & $1: 0.81$ \\
IV & 345 & 28.56 & 132 & 10.93 & 477 & 39.49 & $1: 0.38$ \\
V & 319 & 26.41 & 30 & 2.48 & 349 & 28.89 & $1: 0.09$ \\
\hline Total & 871 & 72.10 & 337 & 27.90 & 1208 & 100.00 & $1: 0.39$ \\
\hline
\end{tabular}

Table 2

Length and weight at age of Chondrostoma holmwoodii population of Tahtalı Dam Lake

\begin{tabular}{|c|c|c|c|c|c|c|c|c|c|c|}
\hline \multirow{2}{*}{ Sex } & \multirow{2}{*}{$\begin{array}{l}\text { Age } \\
\text { group }\end{array}$} & \multirow{2}{*}{$n$} & \multicolumn{4}{|c|}{ Fork length $[\mathrm{cm}]$} & \multicolumn{4}{|c|}{ Weight $[\mathrm{g}]$} \\
\hline & & & Min & Max & Mean \pm CI & $\mathrm{SD}$ & Min & Max & Mean \pm CI & $\mathrm{SD}$ \\
\hline \multirow{5}{*}{ Female } & I & 14 & 14.40 & 16.20 & $15.49 \pm 0.344$ & 0.596 & 44.30 & 79.80 & $59.48 \pm 5.319$ & 9.214 \\
\hline & II & 69 & 16.30 & 19.20 & $17.81 \pm 0.187$ & 0.778 & 61.30 & 118.90 & $93.11 \pm 3.655$ & 15.182 \\
\hline & III & 124 & 17.90 & 21.20 & $19.64 \pm 0.123$ & 0.693 & 91.40 & 185.00 & $128.82 \pm 3.750$ & 21.088 \\
\hline & IV & 345 & 19.50 & 24.00 & $21.37 \pm 0.086$ & 0.815 & 109.80 & 250.30 & $170.63 \pm 2.462$ & 23.240 \\
\hline & $\mathrm{V}$ & 319 & 20.50 & 24.70 & $22.48 \pm 0.095$ & 0.866 & 123.90 & 260.80 & $195.63 \pm 2.610$ & 23.683 \\
\hline \multirow{5}{*}{ Male } & I & 13 & 13.60 & 16.20 & $15.45 \pm 0.439$ & 0.726 & 38.00 & 66.50 & $52.98 \pm 5.313$ & 8.791 \\
\hline & II & 62 & 16.00 & 19.20 & $17.34 \pm 0.229$ & 0.903 & 53.50 & 130.80 & $80.04 \pm 4.055$ & 15.966 \\
\hline & III & 100 & 17.90 & 21.20 & $19.61 \pm 0.135$ & 0.681 & 71.70 & 166.70 & $123.03 \pm 3.660$ & 18.419 \\
\hline & IV & 132 & 19.50 & 23.40 & $20.83 \pm 0.115$ & 0.665 & 112.70 & 202.10 & $147.61 \pm 3.052$ & 17.712 \\
\hline & $\mathrm{V}$ & 30 & 20.50 & 24.00 & $21.85 \pm 0.330$ & 0.883 & 128.00 & 237.00 & $166.81 \pm 9.027$ & 24.176 \\
\hline \multirow{5}{*}{ Female + Male } & $\mathrm{I}$ & 27 & 13.60 & 16.20 & $15.47 \pm 0.262$ & 0.662 & 38.00 & 79.80 & $56.35 \pm 3.791$ & 9.580 \\
\hline & II & 131 & 16.00 & 19.20 & $17.59 \pm 0.151$ & 0.873 & 53.50 & 130.80 & $86.92 \pm 2.919$ & 16.871 \\
\hline & III & 224 & 17.90 & 21.20 & $19.63 \pm 0.091$ & 0.688 & 71.70 & 185.00 & $126.23 \pm 2.655$ & 20.148 \\
\hline & IV & 477 & 19.50 & 24.00 & $21.22 \pm 0.073$ & 0.814 & 109.80 & 250.30 & $164.26 \pm 2.175$ & 24.157 \\
\hline & $\mathrm{V}$ & 349 & 20.50 & 24.70 & $22.43 \pm 0.093$ & 0.885 & 123.90 & 260.80 & $193.15 \pm 2.640$ & 25.063 \\
\hline
\end{tabular}

The von Bertalanffy growth equations of the population were computed as $L_{\infty}=29.19 \mathrm{~cm}$ and $W_{\infty}=438.80 \mathrm{~g}$ (Table 3 ). 
relation were estimated as significant $(t=115.63, P<0.05$ for females, $t=71.78, P<0.05$ for males and $t=144.00$, $P<0.05$ for sex combined). These values suggested that growth in the population was regular.

The instantaneous natural mortality coefficient $(M)$ was calculated as 0.44 when the both sexes are carried out. This value can be accepted as the total mortality ratio because there is no fisheries activity in the study area. individual was sampled in the area. Therefore, our $L_{\infty}$ and $W_{\infty}$ values are also higher than those of reported by Mermer and Balık (1991) (Table 5). We think that absence of fisheries activities in the area can be one of the main reasons for the higher $L_{\infty}$ and $W_{\infty}$ values in our study. Similarly, the lake form of the species is generally bigger than the riverine forms, and our results also support this statement.

Table 3

The von Bertalanffy growth parameters of Chondrostoma holmwoodii population of Tahtalı Dam Lake

\begin{tabular}{lccccc}
\hline & $n$ & $k\left(\right.$ year $\left.^{-1}\right)$ & $t_{0}($ year $)$ & $L_{\infty}[\mathrm{cm}]$ & $W_{\infty}[\mathrm{g}]$ \\
\hline Female & 871 & 0.211 & -2.865 & 27.75 & 364.56 \\
Male & 337 & 0.223 & -2.965 & 26.30 & 301.38 \\
Female + Male & 1208 & 0.177 & -3.258 & 29.19 & 438.80 \\
\hline
\end{tabular}

Table 4

Parameters of the length-weight relation $\left(W=a L^{b}\right)$ of Chondrostoma holmwoodii population of Tahtalı Dam Lake

\begin{tabular}{lcccccc}
\hline Sex & $a$ & $b$ & SE $(b)$ & $n$ & $r^{2}$ & $t$-test \\
\hline Females & 0.01878 & 2.97112 & 0.042428 & 871 & 0.939 & $0.681^{\mathrm{a}}$ \\
Males & 0.01154 & 3.11062 & 0.070609 & 337 & 0.939 & $1.558^{\mathrm{b}}$ \\
All fish & 0.01144 & 3.12845 & 0.035459 & 1208 & 0.945 & $3.606^{\mathrm{c}}$ \\
\hline
\end{tabular}

a $(t$-test, $t>t 0.05,871=1.65) ; b(t$-test, $t>t 0.05,337=1.65) ; \mathrm{c}(t$-test, $t>t 0.05,1208=1.65)$.

Table 5

Age-length and Age-weight values in different studies about Chondrostoma holmwoodii populations

\begin{tabular}{|c|c|c|c|c|c|c|c|c|c|}
\hline \multirow{2}{*}{ Locality } & \multirow{2}{*}{$n$} & & \multicolumn{5}{|c|}{ Age group } & \multirow{2}{*}{$\begin{array}{l}L_{\infty} \\
W_{\infty}\end{array}$} & \multirow{2}{*}{ Reference } \\
\hline & & & I & II & III & IV & $\mathrm{V}$ & & \\
\hline Gediz River $(+\circ)$ & 47 & $\begin{array}{l}L \\
W\end{array}$ & $\begin{array}{l}11.83 \\
20.22\end{array}$ & $\begin{array}{l}15.59 \\
40.44\end{array}$ & $\begin{array}{l}17.77 \\
59.60\end{array}$ & $\begin{array}{l}20.20 \\
86.71\end{array}$ & - & $\begin{array}{r}26.40 \\
161.98\end{array}$ & $\begin{array}{c}\text { Mermer and Balık } \\
\text { (1991) }\end{array}$ \\
\hline Gediz River (ふふぇ) & 43 & $\begin{array}{l}L \\
W\end{array}$ & $\begin{array}{l}11.45 \\
17.08\end{array}$ & $\begin{array}{l}15.34 \\
39.15\end{array}$ & $\begin{array}{l}17.23 \\
53.00\end{array}$ & $\begin{array}{l}18.30 \\
84.88\end{array}$ & - & $\begin{array}{l}19.20 \\
71.47\end{array}$ & $\begin{array}{l}\text { Mermer and Balık } \\
\text { (1991) }\end{array}$ \\
\hline Tahtalı Dam L $(q \uparrow)$ & 871 & $\begin{array}{l}L \\
W\end{array}$ & $\begin{array}{l}15.49 \\
59.48\end{array}$ & $\begin{array}{l}17.81 \\
93.11\end{array}$ & $\begin{array}{r}19.64 \\
128.82\end{array}$ & $\begin{array}{r}21.37 \\
170.63\end{array}$ & $\begin{array}{r}22.48 \\
195.63\end{array}$ & $\begin{array}{r}27.75 \\
364.56\end{array}$ & This study \\
\hline Tahtalı Dam L (ふすَ) & 337 & $\begin{array}{l}L \\
W\end{array}$ & $\begin{array}{l}15.45 \\
52.98\end{array}$ & $\begin{array}{l}17.34 \\
80.04\end{array}$ & $\begin{array}{r}19.61 \\
123.03\end{array}$ & $\begin{array}{r}20.83 \\
147.61\end{array}$ & $\begin{array}{r}21.85 \\
166.81\end{array}$ & $\begin{array}{r}26.30 \\
301.38\end{array}$ & This study \\
\hline
\end{tabular}

\section{DISCUSSION}

In the presently reported study, the sex composition for the Chondrostoma holmwoodii specimens sampled from the Tahtalı Reservoir was $72.10 \%$ females and $27.90 \%$ males, which were distributed among the age groups I-V for both sexes. The female : male ratio was $1: 0.39$. A few specimens belonging to age group I were found in the sampling period. This may be attributed to predation by European perch (Perca fluviatilis) and the mesh size of the nets used in sampling. Mermer and Balık (1991) reported a sex ratio of $1: 0.91$ for age groups between I and IV in the Gediz River

In comparison of the mean lengths and weight values pertaining to age group, our results are higher than Mermer and Balık (1991) in Gediz River, The asymptotic length value $\left(L_{\infty}\right)$ is related to the size of the largest
Consequently, prohibition of fisheries activity can be a chance for persistence of the stock. As an endemic species confined to a limited geographical area Chondrostoma holmwoodii is potentially at risk of extinction due to pollution, drought, dam construction, habitat degradation, and overfishing. However, at present it appears that this species is not threatened by these factors in the surveyed area.

\section{REFERENCES}

Anonymous 2007. Devlet Su İşleri Genel Müdürlüğü. [General Directorate of State Hydraulic Works.] [Downloaded on 5 April 2007.] www.dsi.gov.tr. [In Turkish].

Balık S. 1979. Batı Anadolu Tatlısu Balıklarının Taksonomisi ve Ekolojik Özellikleri Üzerine Araştırmalar. [Investigations of taxonomic and ecological features of freshwater fishes of western Anatolia.] Ege Üniversitesi Fen Fakültesi İlmi 
Raporlar Serisi No: 236 (Doktora Tezi), 61 s. [Ege University Faculty of Science Scientific Reports Series. No. 236. (Doctorate Thesis)] [In Turkish.]

Balık S., Ustaoğlu M.R., Sarı H.M., Aygen C. 1995. Tahtalı Baraj Havzasının (Gümüldür-İzmir) Omurgalı Faunası. [The vertebrate fauna of Tahtalı Dam Lake Basin (Gümüldür-İzmir). II.] Pp. 463-472. In: II. Ulusal Ekoloji ve Çevre Kongresi. 11-13 Eylül, Ankara, 463-472. [National Ecology and Environment Congress. September 11-13, Ankara.] [In Turkish].

Boulenger G.A. 1896. On freshwater fishes from Smyrna. The Annals and Magazine of Natural History 18: 153-154.

Crivelli A. J. 2006. Chondrostoma holmwoodii. In: IUCN 2009. IUCN Red List of Threatened Species. Version 2009.2. [Downloaded on 11 August 2009.] www.iucnredlist.org

Elvira B. 1987. Taxonomic revision of the genus Chondrostoma Agassiz, 1835 (Pisces, Cyprinidae). Cybium 11 (2): 111-140.

Froese R., Pauly D. (eds.) 2009. FishBase. [version 04/2009] http://www.fishbase.org.

Karaman M. 1969. Süßwasserfische der Türkei. 7. Teil. Revision der kleinasiatischen und vorderasiatischen Arten des Genus Capoeta (Varicorhinus, partim). Mitteilungen aus dem Hamburgischen Zoologischen Museum und Institut 66: $17-54$.

Karaman M.S. 1972. Süßwasserfische Der Türkei. 9. Teil Revision Einiger kleinwüchsiger Cyprinidengattungen Phoxinellus, Leucaspius, Acanthobrama usw. Aus Südeuropa, Kleinasien, Vorder-Asien und Nordafrica. Mitteilungen aus dem Hamburgischen Zoologischen Museum und Institut 69: 115-155.

Kosswig C., Battalgil F. 1943. Beitrage zur Türkischen Faunengeschichte. I. Süsswasserfische. Comptes Rendus de la Société Turque des Sciences Physiques, Istanbul 8: 32-60.

Ladiges W. 1960. Süßwasserfische der Türkei. 1. Teil. Cyprinidae. Mitteilungen aus dem Hamburgischen Zoologischen Museum und Institut 58: 105-150.
Ladiges W. 1966. Süßwasserfische der Türkei. 4. Teil. Die Gattung Chondrostoma (Cyprinidae) in der Türkei. Mitteilungen aus dem Hamburgischen Zoologischen Museum und Institut 63: 101-109.

Mermer A., Balık S. 1991. Gediz Nehrindeki Kababurun Balığ 1 (Chondrostoma nasus Linnaeus, 1758) Populasyonunun Biyolojik Yönden İncelenmesi. [Biological investigation on a population of the nase (Chondrostoma nasus Linnaeus, 1758) in the Gediz River.] Ege Üniversitesi Fen Bilimleri Enstitüsü Dergisi İzmir 2 (1): 17-23. [In Turkish.]

Pauly D. 1980. On the interrelationships between natural mortality, growth parameters, and mean environmental temperature in 175 fish stocks. Journal du Conseil-Conseil international pour l'Exploration de la Mer 39 (2): 175-192.

Pellegrin J. 1928. Les poissons des eaux douces d'AsieMineure. J.-B. Baillière et Fils, Paris (Extrait du tome second et dernier du Voyage zoologique d'Henri Gadeau de Kerville en Asie-Mineure (Avril-Mai 1912)).

Ricker W.E. 1975. Computation and interpretation of biological statistics of fish populations. Bulletin of the Fisheries Research Board of Canada 191: 1-382.

Sparre P., Ursin E., Venema S.C. 1989. Introduction to tropical fish stock assessment. Part 1. Manual, FAO Fisheries Technical Paper No. 306/1. FAO, Roma.

Tesch F.W. 1970. Age and growth. Pp. 93-123. In: Ricker W.E. (ed.), Methods for assessment of fish production in fresh waters. IBP Handbook. Blackwell Scientific Publications, Oxford and Edinburg.

Received: 3 September 2009

Accepted: 10 November 2010

Published electronically: 15 December 2010 